\title{
The Underground Architecture
}

\section{Case Study - Cellars in Formeselhe, Spain}

\author{
Manuel Diogo, Maria Diogo, Joana Diogo, Patricia Diogo \\ Researcher in CEPESE \\ Faculty of Architecture and Arts \\ University Lusíada North; Researcher in CITAD
}

\begin{abstract}
Considering that the research intends to analyze the physical, human, historical and socio-economic aspects of the international parks of the Douro that frame the architecture of the subterranean cellars of Fermoselle, the structure is organized around the following points: by one side we analyse the Physical aspects of the territory through summary characterization that will help in understanding the place and the Historical and socioeconomic evolution of the peoples of the transboundary range; By the other side the Case study that supports the study about Underground cellars of Fermoselle - theoretical and practical aspects, essential to the sustainability of the theme. The objective of the research is based on the principle that it is essential to know the vernacular architecture to preserve what remains of it, leaving contributions to safeguard the patrimonial values of greater permanence transported by its own history and tradition until the present day.
\end{abstract}

Keywords - Underground Architecture; Memory and Identity; Protection and Safeguard;

\section{INTRODUCTION}

The present research intends to contribute to add scientific knowledge to the state of the art on the morphotypology of occupation in border territory, in this case, as a geographical support the Spanish territory of Fermoselhe de Sayago located in the Natural Park of Arribes del Duero, in continuity with the Natural Park of the International Douro on the Portuguese side. The scientific interface is established with the Research Center of CITAD - Territory, Architecture and Design Research Center, Lusíada Universities; CEPESE - Center for Studies on Population Economy and Society, University of Porto; School of Architecture of the University of Valladolid; and with the EGTC - European Grouping of Territorial Cooperation, Duero / Douro, which has added common development concerns to all the municipalities that make up the two Natural Parks.

\section{PHYSICAL, HUMAN, HISTORICAL AND SOCIO- ECONOMIC ASPECTS}

\section{A. Physical characterization and human occupation}

The characterization of the physical environment of this relief unit, which extends through the region of Sayago and the Mirandese plateau, forms a narrow fringe that accompanies the river Douro, drawing on its banks a system of terraced terraces consisting of granite rocks, migmatites, quartzites, shales and gneisses[1] that gives rise to a steep landscape of light and clay texture not suitable for agricultural practice as we observe in fig.1.

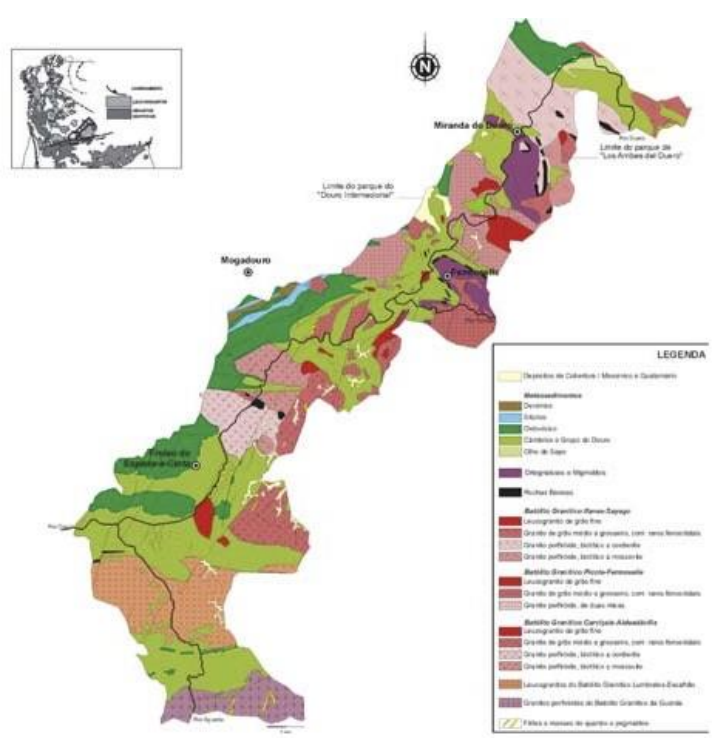

Fig. 1 - Simplified geological map of the region covered by the Douro International Natural Parks / Ribes del Duero.

In fact, these rock formations that were shaped by erosion processes are characterized by low-textured soils with a rough and slightly acidic texture, suitable for pasture production as we observe in fig. 2 .

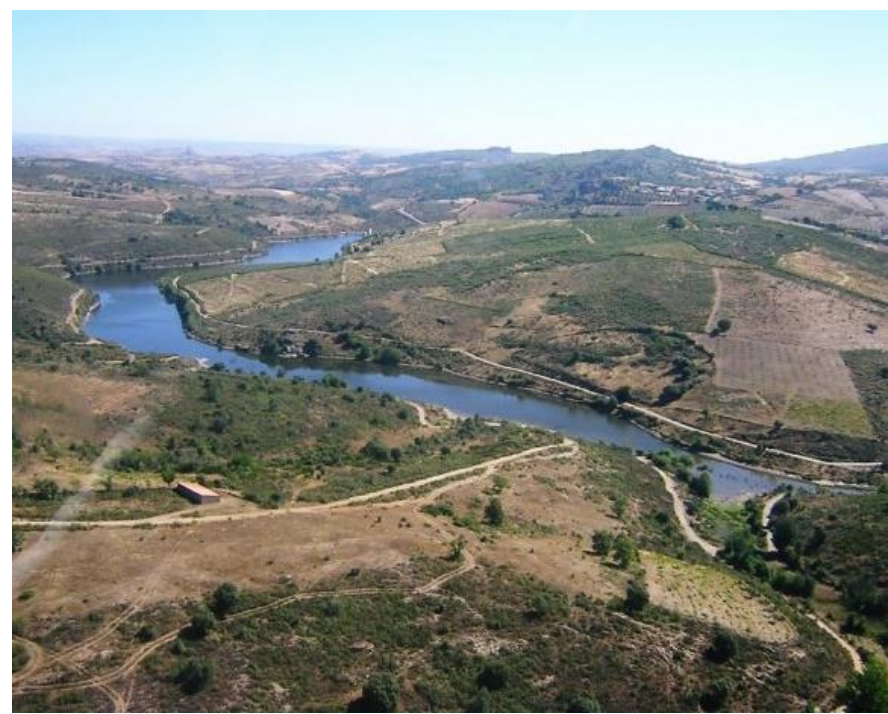

Fig. 2 - Natural Park of International Douro.

From the point of view of occupation of the territory, according to Plínio-o-Velho, most of the castros distributed by the Mirandese plateau, before being romanized, had occupied since 
the Iron Age, the population living in fortified casts located in high places, slopes or in the vicinity of the Douro River and its affluent, notably the casters of Villardiegua de la Ribera which still retains a lot of funerary stelae and a zoomorfa sculpture popularly known as the Villardiegua [2] mule; the remains of the Roman occupation in Fermoselle where punctuates the funerary epigraph dating from the fourth century; or the occupation of the Portuguese side attested by the presence of the Cigadonha [3] castro in Picote, S. João das Arribas castro in Aldeia Nova illustrated in fig.3 [4], and Vale de Águia castro [5], located in the municipality of Miranda do Douro.

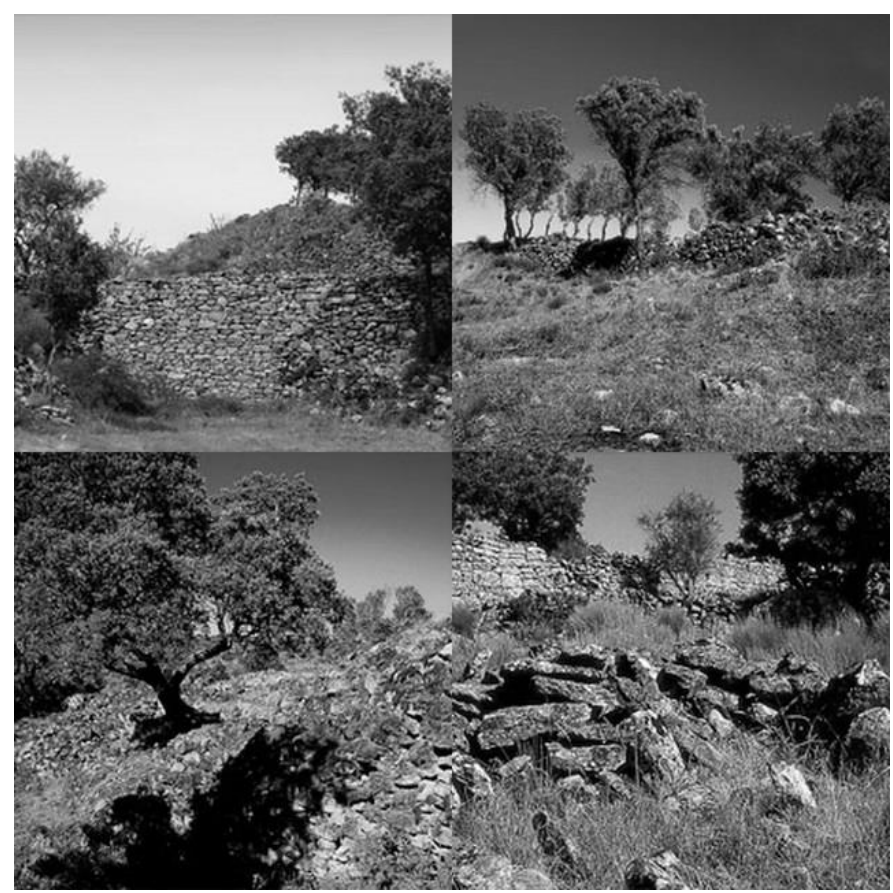

Fig. 3 - Castro of S. João das Arribas in Miranda do Douro.

\section{B. Historical and socio-economic evolution}

Although the purpose of the investigation is not to study the historical process of more than 700 years of separation between the two sides of Europe's oldest political frontier, we must not fail to point out that this medieval political construction still has a significant meaning today. The distance from which it has not been easy to separate because although there is no borderline in the landscape, administrative political demarcations exist and represent conventional symbols in cartography. This means that although borders are not equal and their meanings are not always the same, they nevertheless constitute lines of separation and evoke distance, real or imagined.

These facts lead us to point out that, on the one hand, nature determined specific geographical configurations, on the other hand, human action shaped space with sharp contours, causing imbalances in time and land use processes that reflect standardized strategies associated with a temporal epoch, space and the relationship between man, the environment and modes of occupation.

Or the developmental processes are neither homogeneous nor linear and can be analyzed under dimensions that encompass aspects of a geographical, historical, anthropological and cultural nature. And that in the case of frontier territories they may still be distinguished by their peril, isolation, exodus, devitalization of the economic and social fabric or, as we have already mentioned, they are political dividing lines, physical boundaries and administrative boundaries, but rarely because they are considered territories. convergence, inclusion, complementarity and cooperation.

All studies on demographic dynamics attest that the decrease in population of cross-border settlements is a consequence of the rural exodus and remains a phenomenon that maintains a very low occupation level and a clear depopulation trend attested by the growing demographic void, jeopardizing the minimum population levels necessary to maintain the scarce equipment and services that remain.

\section{CASE STUDY: FERMOSELLE UNDERGROUND WINERIES}

This perspective of isolation observed in fig. 4 and periphery gives a schematic account of the history of crossborder territories and the consequent decay and degradation of the vernacular architecture that characterizes them.

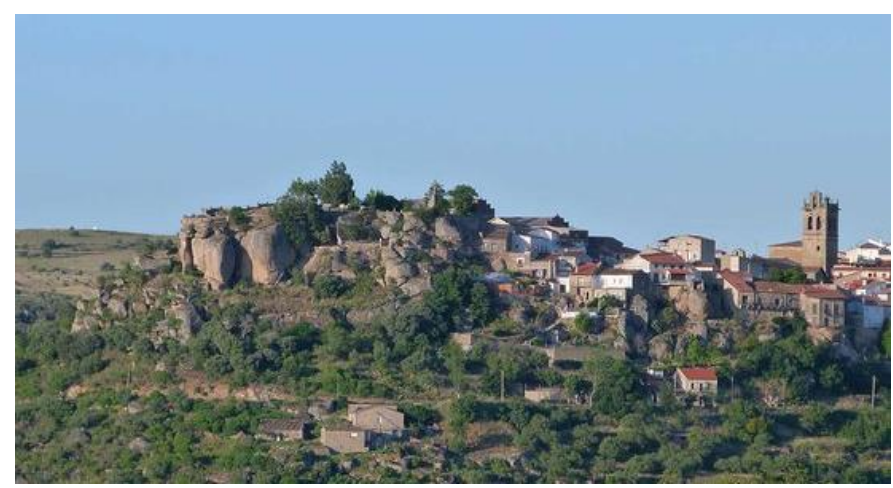

Fig. 4 - View of Fermoselle, Spain

But this process of decline does not always seem to have been so. Despite scarce documentation, the district of Fermoselle - now considered the capital of the Arribas del Duero and "el pueblo de las mil bodegas" - had strong socioeconomic development in the lower middle ages, with the construction of the first underground wineries from the twelfth and thirteenth centuries, during the fifteenth to seventeenth centuries, continuing expansion until the late nineteenth century.

It is assumed, however, that from the mid-twentieth century onwards, the economic and social transformations that took place in the peripheral territories of the Iberian Peninsula, dominated by traditional agriculture in crisis and the absence of job opportunities, favored the emigration flow for the central European countries and Spain's most dynamic urban-industrial centers, which have always offered better expectations of socio-economic achievement, leading to the gradual abandonment of settlements and the consequent increase in the state of decay and decay of vernacular architecture.

But regardless of the historical time and causes that gave rise to rural settlements and the development of popular-rooted architecture, the nature of fermoselle's underground wineries interpret the role played by the men who tore the stone, built terraces on cliffs, jumped rivers and streams, sought water and marked places to live; planted, grafted, pruned, harvested and trampled grapes into mills or mills; they stored and transferred the wine, creating an architecture that arouses emotion in a 
confrontation between the basic need to live, the overcoming of fear by venting the subsoil and the uncertainty that comes from digging into the unknown
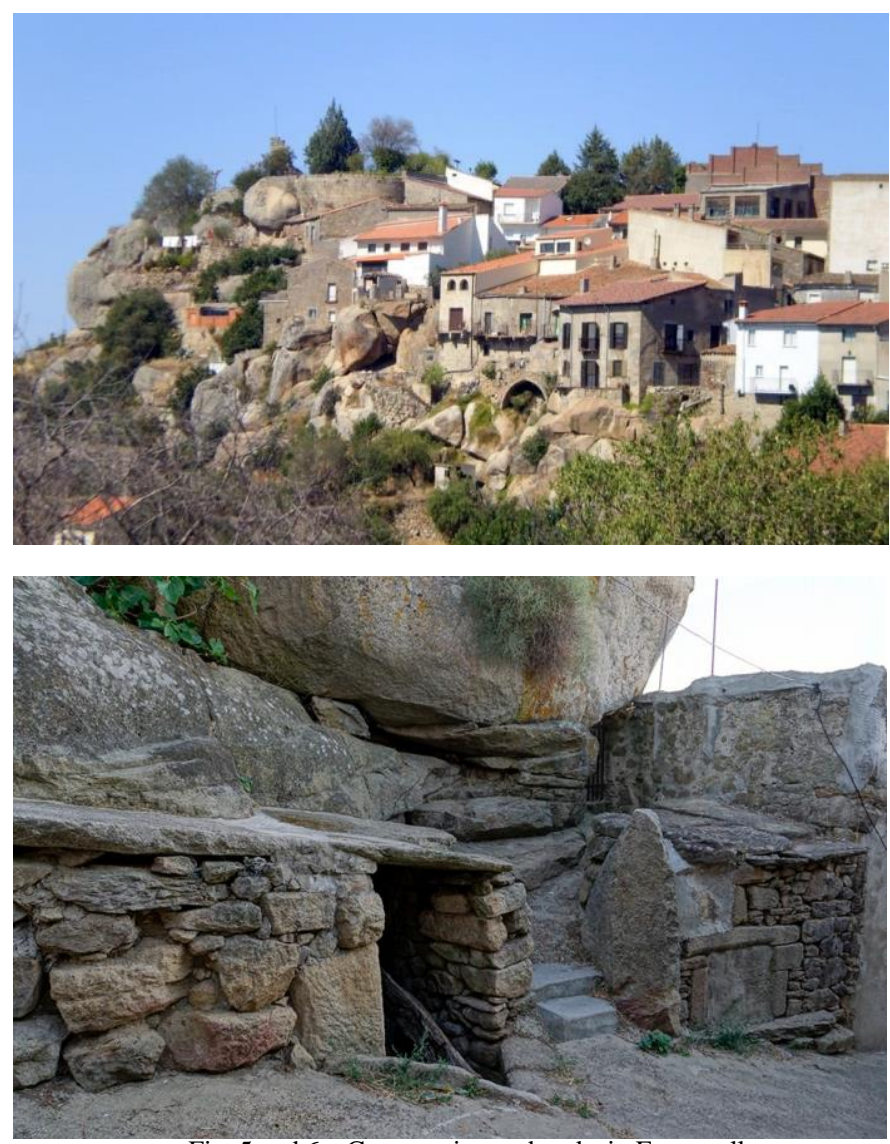

Fig. 5 and 6 - Construction and rocks in Fermoselle.

Dug into the bowels of the rock mass illustrated in fig. 5 and 6 , mostly located on the slopes of the hill that crowns the settlement, the underground wineries constitute a complex network of interconnected vaulted galleries whose spatial monumentality contrasts with the anonymity of the outside, producing a game of feelings and emotions that they are rarely so intensely marked in conventional surface architecture.

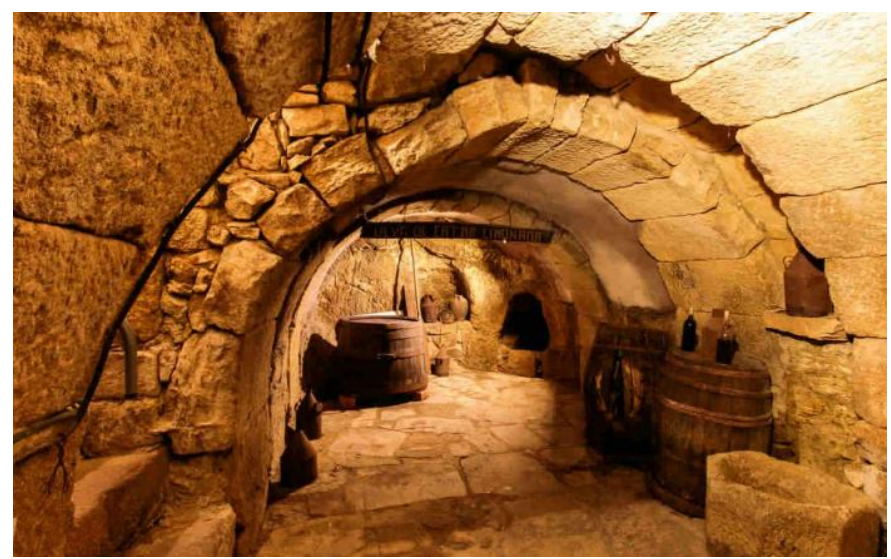

Fig. 7 - Winerie in Fermoselle.

Its interior character illustrated in fig. 7 has been adjusted to the user's needs enhancing a symbiosis architecture between the physical environment and the geological structure, presenting characteristics that provide constant temperature and humidity, essential conditions to cope with the climatic variations resulting from the elevated thermal amplitudes that are felt abroad.

\section{A. Constructive characteristics}

As we mentioned earlier, the construction of underground galleries is known from antiquity, being the system developed during the Middle Ages and continued until approximately the late nineteenth and early twentieth, when there was the great expansion of vineyards in Castilla y León and, with these, the construction of new wineries and mills in order to meet the needs of grape processing and storage of the wine produced and thus prevent its consequent adulteration.

The conceptual process invariably relied on knowledge passed down from generation to generation, starting with locating and starting the ladder at the base elevation of the nave and excavating both sides of the vault's central axis, following alignment of the dwellings that line the streets, until the ship is configured to the desired dimensions.

The fact that Fermoselle's underground wineries, observed in fig.7, are situated on the slope of the hillside that crowns the town, generally grouped with openings oriented to the north or northwest, is now emphasized, sometimes operating inside ancillary buildings or in cellars dug under dwellings.

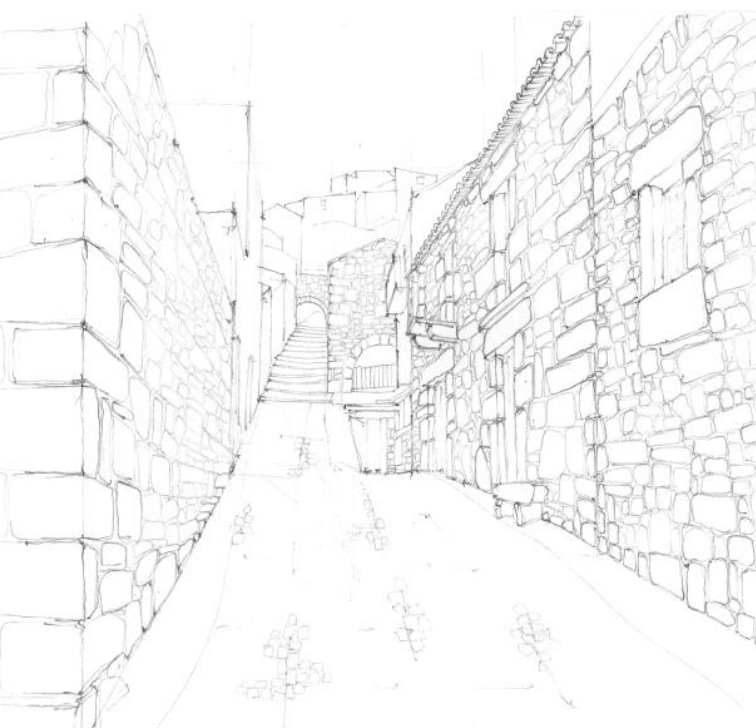

Fig. 8 Drawing of a street in Fermeselle by Joana Diogo

Although its construction is conditioned by the existing constructions as we can observe in fig. 8 , and the underground geological characteristics that require the implementation of more or less complex formal solutions, the depth can vary between 6 and 8 meters or even 12 meters, following labyrinthine paths that crossed streets and adjoining houses, conveying the false sense of being built without following the principles of distribution, width, length and height, and the real mechanical resilience of ships and vaults to compression.

However, in either case, the excavation tended to start from clay, compact, impermeable soil and moisture filter, which provided the safety and working conditions of the vault, until it reached sandy, permeable and poorly compacted soil. from 
which began the layout and the construction process of the galleries.

This means that the access to the wineries corresponds in most cases to the entrance to the dwelling, with access to the nave through a narrow and steep stairway, consisting of a variable number of steps, lined with sandstone and crowned on both sides. inverted V-shaped ceiling or, to a lesser extent, cannon vault.

In fact, these constraints have forced the construction of half-point support arches in the ships, usually in masonry, which work in compression and distribute the construction weight by lateral and diagonal thrust to the support pillars, allowing the opening of larger spans dimensions without risk of collapse and increase the consistency and durability of the structural system.

This constructive system began with the provisional formation of the frame, the formwork, that served as mold for the construction of the interior curvature of the arch observed in fig. 8 and 9 , whose characteristics are invariably present in a few thousand meters of galleries separated by simple doors of rough wood, all built to take advantage of the geological properties of the subsoil that naturally provides stable temperature and humidity throughout the year, in fact, fundamental characteristics for the conservation of wine.

Although the smallness of exterior openings illustrated in Fig. 9 is one of its main characteristics, the ridge is present in all constructions and usually results from the excavation of one side of the side walls of the nave, or from the center of the main nave of the winery, communicating with the exterior through doorways or windows of varying size, coinciding with the line of facades at the lower part of the buildings.

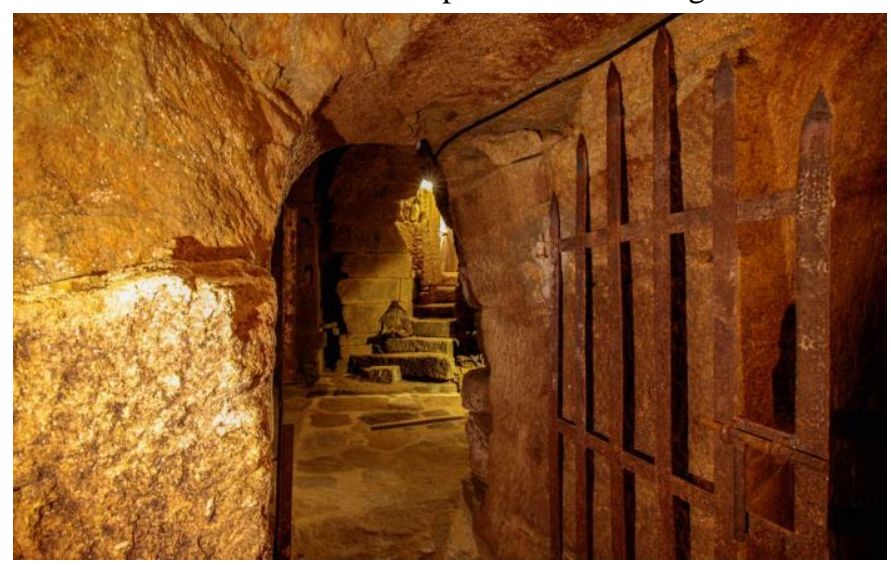

Fig. 9 - Winerie in Fermoselle.

It should be noted that the vents or ventilation chimneys have different functionalities that served to unload the grapes in the winepress, remove the grape marc from the fermentation, serve as a vent and regulate the temperature inside the wineries, as they were used to extract the grapes inert material during construction and, in the end, remove debris that aided the excavation process.

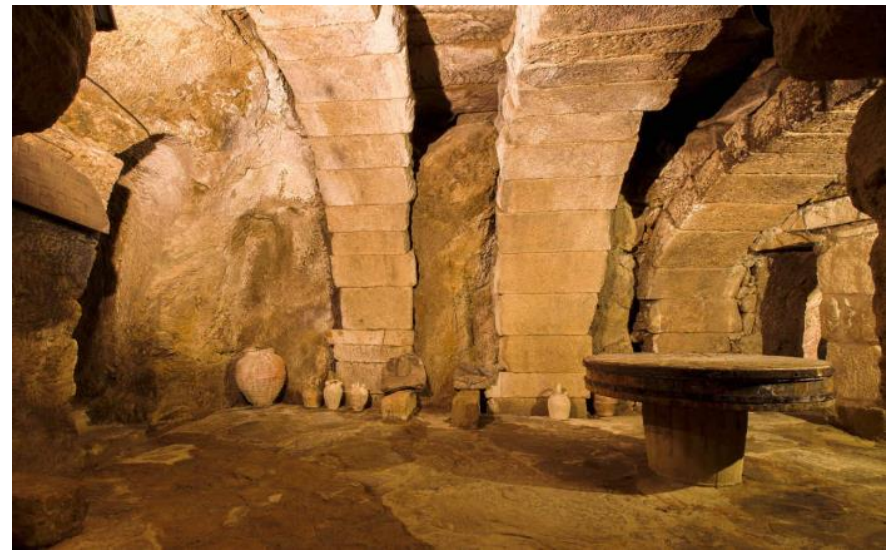

Fig. 10 - Winerie in Fermoselle.

However, this diversity of uses of the rump is not exhausted here, because its main function was to eliminate bad smells from wine fermentation, functioning as a breather, not only because it provides air circulation and transverse ventilation, but also contributes to Maintain stable temperature conditions that oscillate between 12 and 14 degrees throughout the year, including in the most extreme seasons, creating an environment of stillness, serenity and mystery.

\section{B. Memory and Identity}

It is not surprising that these hidden treasures, made up of a network of tunnels connected together, are the matrix that forms authentic mazes that were also, albeit occasionally, used to protect people and property in periods of greater political instability or social.

But not only for this reason, when they lost the initial function that was based on the production, transformation and conservation of wine, their architectural matrix lost its identity - aggravated by the absence of norms that regulate the use of materials and constructive processes - and their unique characteristics and, consequently, the historical, socioeconomic and cultural references that was a carrier.

And the consequences are not only more serious because sociologically the settlement of Fermoselle has traditionally been an agent of cultural and social exchange with the village of Sendim, the villages of Bemposta and Urrós and other neighboring villages, contributing this proximity to promote the flow of water. people and goods that foster commerce and some tourism provided by the rural secular heritage and the Douro International Natural Park, strengthening the connection between the present and the past, between the old and the modern, that is, between the existing and the new.

\section{CONCLUSIONS}

The results of the research depended to a large extent on the methodology adopted, fieldwork, state of the art, scientific articles presented by the team in congresses and journals, as well as other aspects that came to us through orality.

These parameters were the anchor of the analytical study carried out on formal aspects related to underground architecture, namely those related to the architecture of wine production, processing and storage that still exist in the crossborder area of the Douro International Natural Park, Comarca de Fermoselle. 
While we are aware that we cannot draw definitive conclusions from the work done, we conclude that whatever the development strategy for these areas of systematic loss, some of the angles that should be focused on are territorial and social cohesion, and in particular:

- Protection of environmental and cultural values.

- Recovery, safeguarding and enhancement of vernacular architecture;

- Promotion of its sustainable use.

These circumstances reinforce the understanding that rural settlements, with their ancestral heritage - albeit in most cases abandoned - can be powerful factors of distinction and collective identity, as well as anchors of qualification and settlement, development of places and of regions.

This work on Fermoselle is part of an open work that seeks to promote the constitution of heritage inventory anchored in a cross-border comparative analysis, with a view to increasing the body of knowledge sustained in case studies that represent the identity of places and are assets that mobilize in their interregional strategic development processes.

\section{REFERENCES}

[1] Mapa geológico simplificado da região abrangida pelos Parques Naturais do Douro Internacional/Arribes del Duero: http://www.cienciaviva.pt/veraocv/2008/downloads/Douro\%20Norte\%2 008\%20-\%20web.pdf

[2] "Atlas de la Raya", Zamora/Trás-Os-Montes. Deputación de Zamora, Área de Iniciativas Económicas y Asuntos Europeos: Gráficas Lope. 2009.

[3] Baeza, Alberto Campo, "Pensar com as mãos", Casal de Cambra, Caleidoscópio, 2011.
[4] Canas I., Mazarrón F.R., "The effect of traditional wind vents called zarceras on the hygrothermal behaviour of underground wine cellars in Spain", p.44, 2009.

[5] Comino, Mario Algarín, "Arquitecturas Excavadas", Arquithesis, 2006 Barcelona.

[6] Fernández Portela, J., "Las Bodegas Tradicionales: Patrimonio Olvidado en la Cultura del vino en la denominación de Origen de Cigales", Universidad de Zaragoza. Departamento de Geografía; Instituto de Geografía Aplicada, pp. 61-86, Castilla y León 2014.

[7] Ferreira N., Brilha J., Dias G., Castro P., M. I. C. Alves, Pereira D., (2003), "Património Geológico do Parque Natural do Douro Internacional (NE de Portugal): caracterização de locais de interesse geológico", Ciências da Terra, UNL, Número especial, V CD-ROM, pp. 140-142, Lisboa, 2003.

[8] Gomes, M.E.P., Sousa, L., Coke, C. \& Lourenço, J.M., "Enquadramento geomorfológico e geológico das barragens de Miranda do Douro, Picote e Bemposta. Livro de Resumos do Encontro Ibérico sobre Património Geológico Transfronteiriço na Região do Douro, Freixo de Espada à Cinta, pp. 53-56, 2005.

[9] Huetz de Lemps, A., Vinos y viñedos de Castilla y León, Consejería de Agricultura y Ganadería de la Junta de Castilla y León, Valladolid, pp. 683, 2005.

[10] Iglesia Berzosa, J., "Viñedo, vino y bodegas en la historia de Aranda de Duero", Ayuntamiento de Aranda de Duero, pp.86

[11] Lemos, Francisco Sande, "Povoamento Romano de Trás-os-Montes Oriental", dissert. de doutoramento, vol. IIa, Universidade do Minho, pp. 202-206, Braga 1993.

[12] López-Plaza, M. \& López-Moro, F.J., "Asentamiento humano en relación con plutones graniticos tabulares: el caso de Fermoselle", Livro de Resumos do Encontro Ibérico sobre Património Geológico Transfronteiriço na Região do Douro, Freixo de Espada à Cinta, pp.2933, Zamora, 2005.

[13] Veiga da Cunha, Luís, "Desenho Técnico", Fundação Calouste Gulbenkian, Lisboa.

[14] Villahoz, A., "Bodegas y zarceras", Universidad Autónoma de Madrid. Facultad de Filosofía y Letras. Narria: Estudios de artes y costumbres populares, Madrid, 1982. 